\title{
TATA NIAGA HASIL BUDIDAYA IKAN MAS (Cyprinus carpio) DI KECAMATAN PAMIJAHAN KABUPATEN BOGOR JAWA BARAT
}

\author{
M. Reza ${ }^{1}$, Edward D. Kusumah ${ }^{2}$ \\ ${ }^{1,2)}$ Fakultas Ilmu Kelautan dan Perikanan Universitas Satya Negara Indonesia \\ Jalan Arteri Pondok Indah No:11, Jakarta Selatan 12240 \\ Email : rezaarchytirema@ymail.com
}

\begin{abstract}
Carp ( cyprinus carpio ) is one of commodities a food fish fresh water in indonesia Commercial distribution is the activity that pertains to the creation or change usefulness than goods and services, then commercial distribution of including a productive activities Local one centers of production carp in kabupaten bogor is kecamatan pamijahan besides kecamatan ciseeng Fish produced fish consumption is size ( $300-700 \mathrm{~g} /$ tail ) to measure anglers with weights at least $1,5 \mathrm{~kg} /$ tail Marketing in kecamatan pamijahan consisting of four agencies marketing and into three a groove marketing. A groove marketing first are of the manufacturer and to the consumer end so no value margin marketing. The total value of margins from a groove marketing for the second Rp.5.000 and a groove into three of Rp.5.500 .
\end{abstract}

\section{Key words: Carp, groove marketing, marketing margin, Pamijahan sub-district}

\begin{abstract}
ABSTRAK
Ikan Mas (Cyprinus carpio) merupakan salah satu komoditi ikan konsumsi air tawar di Indonesia. Tata Niaga adalah kegiatan yang bertalian dengan penciptaan atau perubahan kegunaan daripada barang dan jasa, maka tata niaga termasuk kegiatan yang produktif. Daerah yang menjadi salah satu sentra produksi ikan Mas di Kabupaten Bogor adalah Kecamatan Pamijahan selain Kecamatan Ciseeng. Ikan yang diproduksi merupakan ikan ukuran konsumsi (300 - 700 g/ekor) hingga ukuran pemancing dengan bobot minimal 1,5 kg/ekor. Pemasaran di Kecamatan Pamijahan terdiri dari empat lembaga pemasaran dan menjadi tiga alur pemasaran. Alur pemasaran pertama ialah dari dari produsen lalu ke konsumen akhir sehingga tidak ada nilai marjin pemasaran. Nilai total marjin dari alur pemasaran kedua sebesar Rp.5.000 dan alur ke tiga sebesar Rp.5.500.
\end{abstract}

Kata kunci: Ikan Mas, Alur Pemasaran, Marjin Pemasaran, Kecamatan Pamijahan 


\section{PENDAHULUAN}

Ikan merupakan salah satu komoditi perikanan yang memberikan kontribusi bagi konsumsi protein penduduk Indonesia. Kandungan gizi pada ikan air tawar cukup tinggi bahkan hampir sama dengan komoditas ikan air laut, sehingga sangat dianjurkan untuk dikonsumsi dengan jumlah cukup banyak. Tingginya kandungan vitamin dan kandungan lain yang dimiliki, diantaranya Omega-3, Omega-6, dan DHA, sangat membantu pertumbuhan balita (Anggaini, 2008).

Ikan Mas merupakan salah satu produk perikanan budidaya yang menjadi salah satu andalan di wilayah Kabupaten Bogor selain ikan Lele (Clarias sp.). Budidaya ikan Mas di Kabupaten Bogor telah berlangsung lama sekitar lebih dari 30 tahun yang dimulai sejak akhir tahun 1970 an. Sistem budidaya (pembesaran) yang menggunakan sistem Kolam Air Deras (KAD) dengan sumber air berasal dari sungai yang mengalir. Pemasaran ikan biasanya tidak dilakukan oleh satu tangan tetapi dilaksanakan oleh beberapa perantara, baik besar maupun kecil, sehingga membentuk mata rantai yang panjang. Mata rantai yang panjang akan mengakibatkan biaya pemasaran menjadi tinggi karena tiap perantara ingin mendapatkan keuntungan untuk menutup biaya pemasaran yang telah dikeluarkan. Besarnya keuntungan pemasaran dan biaya pemasaran di tingkat perantara merupakan komponen dalam pembentukan harga akhir (harga eceran) di tingkat konsumen. Hal ini akan berpengaruh pada harga di tingkat produsen, bahkan dapat menekan harga ditingkat produsen karena daya beli sebagian konsumen masih terbatas (Noviana, 2003).

Sistem alur pemasaran ikan di daerah penelitian kebanyakan petani menjual ikan kepada tengkulak yang datang langsung kepada mereka sehingga keuntungan yang mereka dapatkan tergolong rendah karena tidak selalu menjual ikan mereka langsung ke konsumen akhir (end user) yang jelas bisa memberikan keuntungan lebih besar kepada mereka. Berdasarkan latar belakang tersebut penulis akan melakukan penelitian berjudul "Tata Niaga Hasil Budidaya Ikan Mas (Cyprinus carpio) di Kecamatan Pamijahan Kabupaten Bogor Jawa Barat”.

Tujuan penelitian ini untuk mengetahuoi bagaimana para petani ikan mengatasi permasalahan dalam pemasaran ikan Mas dan untuk mengetahui bagaimana peran lembaga pemasaran dalam melakukan kegiatan pemasaran di Kabupaten Bogor.

Manfaat dari penelitian ini adalah memberikan informasi kepada masyarakat mengenai alur pemasaran yang terjadi di Kabupaten Bogor dan memberikan masukan dan informasi kepada petani ikan dengan tujuan meningkatkan nilai ekonomi dari kegiatan budidaya ikan tersebut.

\section{METODOLOGI}

Waktu pelaksanaan kegiatan penelitian pendahuluan ini dilakukan selama bulan Januari 2016. Bertempat di Kabupaten Bogor Provinsi Jawa Barat. Jenis data yang diperlukan untuk penelitian pendahuluan ini diperoleh melalui pengatan dan wawancara langsung dengan para pelaku kegiatan budidaya Ikan Mas di Kabupaten Bogor mulai dari petani ikan hingga ke pedagang eceran di pasar (pasar tradisional). Alat yang digunakan dalam penelitian ini adalah : Alat tulis, Laptop, Recorder dan Kuisioner.

Tabel 5. Alat Penelitian

\begin{tabular}{|l|l|l|}
\hline No & Alat & Fungsi \\
\hline 1. & Alat tulis & Untuk mencatat hasil pengambilan data \\
\hline 2. & Laptop & Untuk pengetikan dan pengolahan data \\
\hline 3. & Recorder & Merekam wawancara dengan narasumber \\
\hline 4. & Kuisioner & Mengumpulkan informasi dari narasumber \\
\hline
\end{tabular}


Peneliti melakukan penelitian menggunakan metode kualitatif, dimana peneliti akan membuat angket/kuesioner yang akan diberikan kepada responden secara acak. Responden akan menjawab pertanyaan yang sudah dibuat oleh penulis berupa pertanyaan model pilihan berganda. Penulis juga melakukan wawancara kepada beberapa orang yang menurut penulis akan mampu memberikan jawaban atau respon yang mewakili seluruh sampel populasi, sehingga data yang diperoleh akan lebih akurat. Hasil dari pemberian angket/kuesioner dan wawancara akan dijelaskan secara deskriptif karena menggunakan metode penelitian kualitatif. Marjin pemasaran adalah perbedaan harga yang dibayar kepada produsen dan harga yang dibayar oleh konsumen (Saefudin dan Hanafiah, 1986). Perhitungan analisis marjin pemasaran dilakukan untuk mengetahui perbedaan harga per satuan di tingkat produsen atas di tingkat konsumen yang terjadi pada rantai pemasaran (Sudiyono, 2004). Secara matematis dapat di rumuskan sebagai berikut :

Perhitungan marjin pemasaran :

$$
\begin{gathered}
\mathrm{MP}=\mathrm{Hk}-\mathrm{Hp} \\
\mathrm{MP}=\text { Marjin Pemasaran } \\
\mathrm{Hk}=\text { Harga pada Konsumen } \\
\mathrm{Hp}=\text { Harga pada Produsen }
\end{gathered}
$$

\section{KEADAAN UMUM DAERAH PENELITIAN}

\section{A. Keadaan Wilayah, Topografi, dan Demografi Lokasi Penelitian}

Kecamatan Pamijahan merupakan salah satu daerah administrasi dari Kabupaten Bogor Provinsi Jawa Barat. Secara geografis letak Kecamatan Pamijahan berada di 6²1’37.96 LS dan 106³9'16.06 BT, dengan luas 12.532.36 hektar. Batas administrasi Kecamatan Pamijahan dibatasi dengan :
-Batas Utara
: Kecamatan Cibungbulang
-Batas Barat
: Kecamatan Leuwiliang
-Batas Selatan
: Kecamatan Sukabumi
-Batas Timur
: Kecamatan Tenjolaya

\section{B. Karakteristik Penduduk}

Penduduk Kecamatan Pamijahan dilihat dari tingkat pendidikannya, sangat beragam dengan pendidikan terendah adalah SD/sederajat dan yang tertinggi adalah S2/sederajat. Mayoritas penduduk dengan tingkat pendidikan SD/sederajat yaitu sebanyak 38.503 jiwa dan yang paling sedikit adalah D2/sederajat dengan jumlah dua jiwa. Tabel 6 berikut menjelaskan komposisi penduduk berdasarkan tingkat pendidikannya.

Tabel 6. Komposisi Penduduk Menurut Tingkat Pendidikannya di Kecamatan Pamijahan Tahun 2014.

\begin{tabular}{|c|l|c|c|c|}
\hline No & \multicolumn{1}{|c|}{ Pendidikan } & Laki-laki & Perempuan & Jumlah \\
\hline 1 & SD Sederajat & 18782 & 19721 & 38503 \\
\hline 2 & SMP Sederajat & 10199 & 8472 & 18671 \\
\hline 3 & SMA Sederajat & 6501 & 3653 & 10154 \\
\hline 4 & D2 Sederajat & 531 & 326 & 857 \\
\hline 5 & D3 Sederajat & 2 & 0 & 2 \\
\hline
\end{tabular}




\begin{tabular}{|c|c|c|c|c|}
\hline 6 & S1 Sederajat & 283 & 176 & 459 \\
\hline 7 & S2 Sederajat & 42 & 25 & 67 \\
\hline 8 & S3 Sederajat & 4 & 4 & 8 \\
\hline \multicolumn{2}{|c|}{ Jumlah } & $\mathbf{3 6 3 4 4}$ & $\mathbf{3 2 3 7 7}$ & $\mathbf{6 8 7 2 1}$ \\
\hline
\end{tabular}

Sumber : Data Demografi Kecamatan Pamijahan 2014

Penduduk di Kecamatan Pamijahan berjumlah 106.515 jiwa, dengan jumlah laki laki 57.320 jiwa dan perempuan sebanyak 49.195 jiwa. Mayoritas penduduk berada di kelompok usia 26 - 40 tahun atau berada pada usia produktif sebanyak 29.320 jiwa dan diikuti kelompok usia 41 - 55 tahun dengan jumlah sebanyak 17.328 jiwa. Tabel 7 berikut menjelaskan komposisi penduduk berdasarkan rentang usia.

Tabel 7. Komposisi Penduduk Menurut Kelompok Usia di Kecamatan Pamijahan Tahun 2014.

\begin{tabular}{|l|l|c|c|c|}
\hline No & \multicolumn{1}{|c|}{ Usia } & Laki-laki & Perempuan & Jumlah \\
\hline 1 & Usia 0 - 6 tahun & 4107 & 3772 & 7879 \\
\hline 2 & Usia 7 - 12 tahun & 6880 & 6278 & 13158 \\
\hline 3 & Usia 13 - 18 tahun & 6689 & 6490 & 13179 \\
\hline 4 & Usia 19 - 25 tahun & 7689 & 7924 & 15613 \\
\hline 5 & Usia 26 - 40 tahun & 15547 & 13773 & 29320 \\
\hline 6 & Usia 41 - 55 tahun & 10123 & 7205 & 17328 \\
\hline 7 & Usia 56 - 65 tahun & 3623 & 2129 & 5752 \\
\hline 8 & Usia 66 - 75 tahun & 1715 & 1067 & 2782 \\
\hline 9 & Usia >75 tahun & 947 & 557 & 1504 \\
\hline Jumlah & $\mathbf{5 7 3 2 0}$ & $\mathbf{4 9 1 9 5}$ & $\mathbf{1 0 6 5 1 5}$ \\
\hline
\end{tabular}

Sumber : Data Demografi Kecamatan Pamijahan 2014.

Penduduk di Kecamatan Pamijahan sebagian besar berprofesi sebagai wiraswasta sebanyak 27.097, namun ada hal yang cukup mengejutkan dimana jumlah pengangguran berada di nomor dua terbanyak setelah wiraswasta dengan jumlah sebanyak 20.114 jiwa. Ini masih menandakan belum tersedianya lapangan kerja yang mampu menyerap tenaga kerja lebih besar di wilayah tersebut dan masih rendahnya tingkat pendidikan penduduk Kecamatan Pamijahan. Tabel 8 berikut menjelaskan komposisi penduduk menurut jenis pekerjaannya di Kecamatan Pamijahan.

Tabel 8. Komposisi Penduduk Menurut Jenis Pekerjaannya di Kecamatan Pamijahan Tahun 2014.

\begin{tabular}{|l|l|l|l|l|}
\hline No & Jenis Pekerjaan & Laki-laki & Perempuan & Jumlah \\
\hline 1 & Petani & 1147 & 38 & 1185 \\
\hline 2 & Buruh tani & 3330 & 143 & 3473 \\
\hline 3 & Pegawai Negeri Sipil & 236 & 65 & 301 \\
\hline 4 & Pengrajin & 5 & 4 & 9 \\
\hline 5 & Pedagang barang kelontong & 5 & 1 & 6 \\
\hline 6 & Peternak & 63 & 11 & 74 \\
\hline 7 & Nelayan & 17 & 1 & 18 \\
\hline 8 & Montir & 22 & 0 & 22 \\
\hline 9 & Dokter swasta & 4 & 3 & 7 \\
\hline 10 & Perawat swasta & 0 & 11 & 11 \\
\hline 11 & TNI & 44 & 0 & 44 \\
\hline 12 & POLRI & 16 & 0 & 16 \\
\hline
\end{tabular}




\begin{tabular}{|c|c|c|c|c|}
\hline 13 & $\begin{array}{l}\text { Pengusaha kecil, menengah, dan } \\
\text { besar }\end{array}$ & 312 & 156 & 468 \\
\hline 14 & Guru swasta & 226 & 243 & 469 \\
\hline 15 & Dosen swasta & 10 & 0 & 10 \\
\hline 16 & Pedagang keliling & 2053 & 139 & 2192 \\
\hline 17 & Tukang kayu & 62 & 0 & 62 \\
\hline 18 & Tukang batu & 53 & 0 & 53 \\
\hline 19 & Pembantu rumah tangga & 20 & 270 & 290 \\
\hline 20 & Karyawan perusahaan swasta & 2976 & 706 & 3682 \\
\hline 21 & Karyawan perusahaan pemerintah & 83 & 29 & 112 \\
\hline 22 & Wiraswasta & 17940 & 9157 & 27097 \\
\hline 23 & Belum bekerja & 10539 & 9575 & 20114 \\
\hline 24 & Pelajar & 8270 & 7712 & 15982 \\
\hline 25 & Ibu rumah tangga & 217 & 21088 & 21305 \\
\hline 26 & Purnawirawan/pensiunan & 256 & 55 & 311 \\
\hline 27 & Perangkat desa & 63 & 6 & 69 \\
\hline 28 & Buruh harian lepas & 5310 & 269 & 5579 \\
\hline 29 & $\begin{array}{l}\text { Pemilik usaha jasa transportasi dan } \\
\text { perhubungan }\end{array}$ & 54 & 1 & 55 \\
\hline 30 & Kontraktor & 12 & 0 & 12 \\
\hline 31 & Sopir & 661 & 3 & 664 \\
\hline 32 & Tukang jahit & 124 & 5 & 129 \\
\hline 33 & Tukang rias & 7 & 5 & 12 \\
\hline 34 & Karyawan honorer & 104 & 31 & 135 \\
\hline 35 & Tukang las & 26 & 2 & 28 \\
\hline 36 & Tukang gigi & 2 & 0 & 2 \\
\hline 37 & Tukang listrik & 10 & 0 & 10 \\
\hline 38 & Pemuka agama & 128 & 14 & 142 \\
\hline 39 & Anggota legislative & 12 & 1 & 13 \\
\hline \multicolumn{2}{|c|}{ Jum lah } & 54419 & 49744 & 104163 \\
\hline
\end{tabular}

Sumber : Data Demografi Kecamatan Pamijahan 2014

\section{HASIL DAN PEMBAHASAN}

\section{A. Petani Ikan}

Petani ikan di Kabupaten Bogor sudah memulai usaha budidaya ikan Mas sejak akhir tahun 1970an dan terus berlangsung hingga sekarang. Sebagian besar pelaku kegiatan budidaya ikan Mas saat ini mewarisi usaha mereka secara turun temurun. Usaha budidaya ikan Mas di Kabupaten Bogor dilakukan oleh masyarakat yang secara umum mendiami daerah tersebut, namun dalam beberapa tahun terakhir banyak warga pendatang dari daerah luar Kabupaten Bogor yang datang dan membeli lahan untuk memulai kegiatan budidaya ikan air tawar khususnya ikan Mas dan hal ini banyak terjadi di Kecamatan Tenjolaya. Hasil pengatan dan wawancara yang dilakukan dengan petani ikan di Kabupaten Bogor diketahui secara umum merupakan kegiatan budidaya ikan yang lebih didominasi oleh kegiatan pembesaran walaupun ada sebagian petani ikan yang sudah mampu melakukan kegiatan budidaya dari fase pembenihan.

\section{B. Lembaga Pemasaran}


Lembaga pemasaran yang terlibat dimulai dari panen ikan ukuran benih sampai ukuran konsumsi yang terdiri dari tengkulak yang biasa membeli dari petani ikan sebagai produsen sampai ke pedagang eceran.

Pemasaran ikan dalam penelitian kali ini dimulai dari petani pembenih ikan di Kabupaten Subang yang menjual ikan hasil pembenihan mereka kepada tengkulak (biasa disebut Bandar oleh petani setempat) lalu pihak bandar tersebut menjual kembali kepada petani pembesar di Kabupaten Bogor. Petani pembesar di Kabupaten Bogor membeli ikan dari subang sekitar 6 bulan sekali. Petani menerima ikan dari Bandar lalu memelihara dalam kurun waktu kurang lebih tiga bulan sampai satu tahun dan menjual kembali ikan tersebut kepada tengkulak atau bisa langsung menjual kepada konsumen akhir (end user). Pemasaran yang terjadi di Kabupaten Bogor hanya melibatkan produsen, tengkulak (pedagang gosir), pedagang eceran, dan konsumen, namun untuk tempat tertentu seperti pasar Parung Bogor menambah lembaga pemasaran yaitu calo atau pedagang perantara.

\section{Pembenihan dan Pembesaran Ikan Mas}

Kegiatan pembenihan di Kabupaten Bogor jarang dilakukan karena beberapa faktor seperti, ketiadaan induk yang baik, kekurangan modal karena perawatan induk yang lebih mahal, sampai ketiadaan tempat/media untuk pemijahan ikan Mas. Karena itu masih cukup banyak petani yang memilih untuk membeli benih ikan Mas dari Subang. Ukuran benih yang biasa dibeli petani dari Kabupaten Subang ialah ukuran 100 ekor/kg dengan harga Rp.32.000 - Rp.38.000.

Ikan yang sudah dibeli lalu ditebar ke kolam pembesaran dan mulai dibudidayakan dengan menggunakan sistem Kolam Air Deras (running water) dan diberikan pakan sebanyak 3 kali sehari. Pakan yang digunakan biasanya merk Laju dan Sinta type floating feed dengan harga Rp.365.000 per karung $(50 \mathrm{Kg})$. ikan dengan bobot $300-700$ g/ekor atau biasa disebut "banci kaleng" dan ukuran 700 - 1000 g/ekor biasa disebut "banci full" bisa menghabiskan pakan sebanyak satu karung $(50 \mathrm{Kg}$ ) selama dua minggu. Ikan yang sudah memasuki ukuran pemancingan atau kelas super konsumsi pakannya bertambah sebanyak $18 \mathrm{Kg}$ dari sebelumnya. Misalkan dalam dua minggu bisa menghabiskan satu karung pakan, kini bertambah menjadi $58 \mathrm{~kg}$. Ikan yang dibudidayakan dalam kegiatan pembesaran ini dilakukan selama tiga bulan pada saat ikan ditebar untuk mencapai ukuran konsumsi ukuran \pm 300 g/ekor. Kegiatan sortir dilakukan satu bulan sekali dan biasanya hasil sortiran ketiga tidak dijual dan dikonsumsi peribadi atau dibuang karena tidak laku di jual di

pasar.

Ukuran ikan kelas super biasanya membutuhkan waktu $2-3$ tahun pemeliharaan. Banyak petani ikan di Kabupaten Bogor yang menggunakan metode panen sebagian sebagai salah satu cara untuk mendapatkan ikan yang mampu mencapai kelas super dalam waktu yang lebih cepat dan kualitas yang baik. Jenis pakan yang digunakan ada dua macam yaitu jenis Laju dan jenis Sinta. Harga pakan Laju Rp.375.000 dan Sinta Rp.390.000 per satu karung (isi 50 kg). Gambar 10 dan 11 di bawah ini adalah jenis pakan yang digunakan yaitu Pakan Merk Laju dan Pakan Merk Sinta 


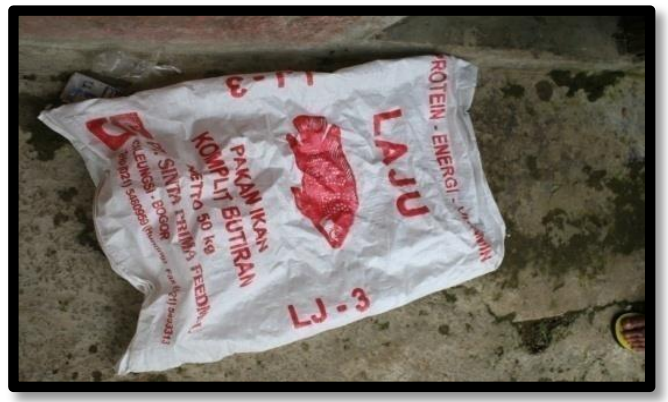

Gambar 10 .Pakan Merk Laju

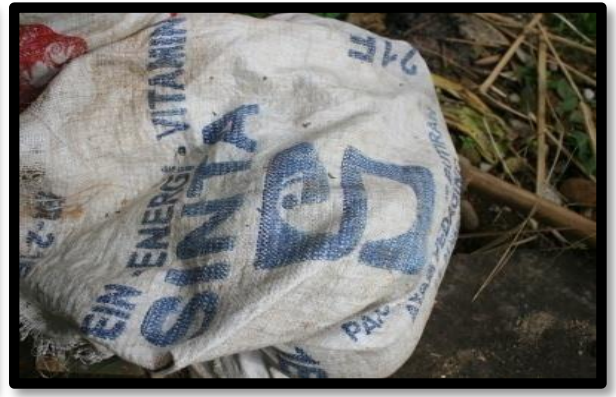

Gambar 11 .Pakan Merk Sinta

Petani ikan di Kecamatan Pamijahan Kabupaten Bogor menggunakan sistem Kolam Air Deras (KAD) dalam Budidaya ikan Mas. KAD merupakan sistem pemeliharaan dengan sumber air berasal dari aliran sungai dan letak tanah berada pada daerah yang agak miring sehingga terbentuk pola air mengalir dengan deras. Gambar 12, 13, 14, 15 di bawah ini menjelaskan teknik pembesaran menggunakan sistem kolam air deras atau running water.

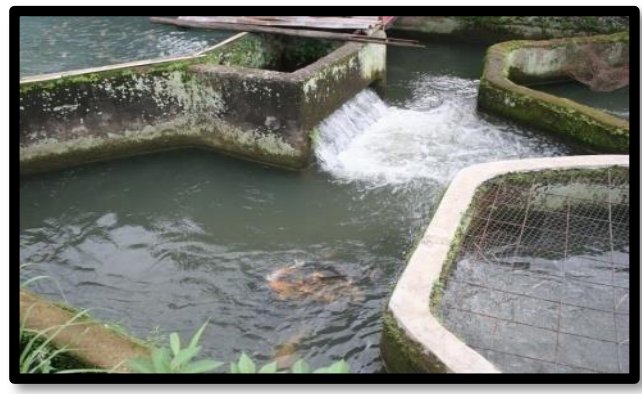

Gambar 12. Proses Air Masuk

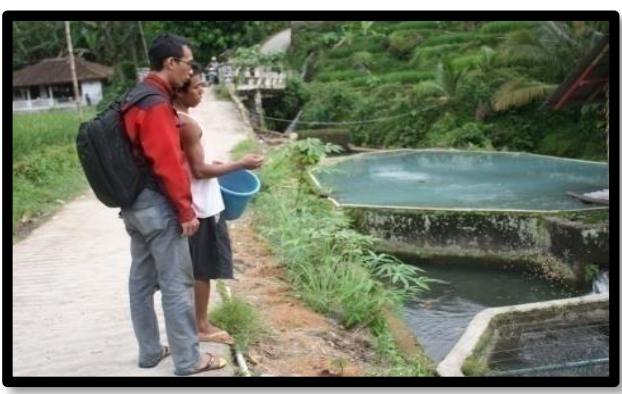

Gambar 14. Pemberian Pakan

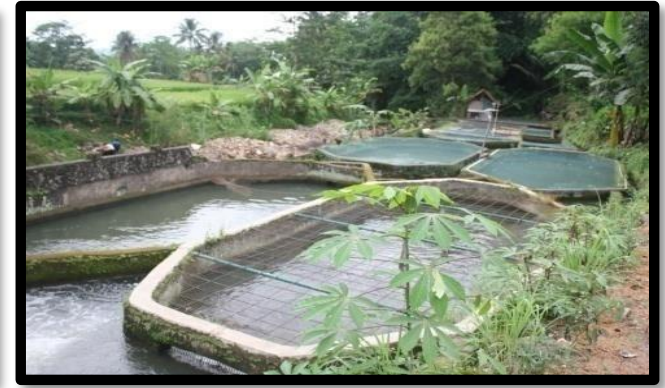

Gambar 13. Arah Air Ke Kolam dari Pintu Masuk

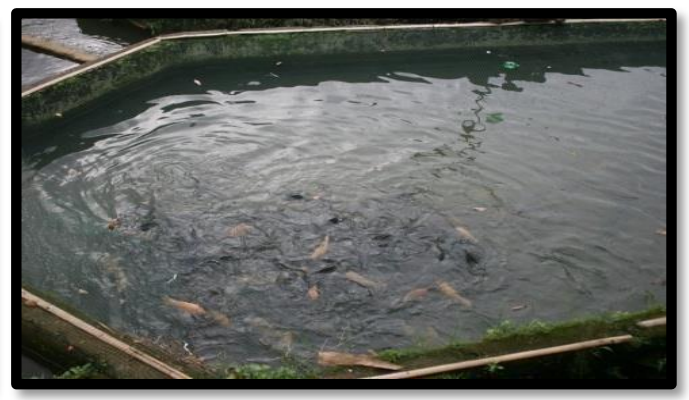

Gambar 15. Ikan yang Dipelihara Dalam Kolam

\section{Proses Panen, Paska Panen, Transportasi Ikan Mas}

Kegiatan panen dilakukan dengan langkah awal melakukan kegiatan pemberokan selama satu hari sebelum diangkat dan dipindahkan ke media transportasi. Proses pemanenan dilakukan dengan menyurutkan volume air di kolam lalu mengangkat jaring atau warring sampai ikan terlihat dan mudah untuk dipindahkan ke media berikutnya. Teknik panen yang dilkaukan tergantung permintaan pembeli namun biasanya petani ikan melakukan panen sebagian dimana tidak semua ikan diangkat melainkan sebagian saja dan sisanya dikembalikan lagi ke kolamnya. Biaya sewa orang untuk melakukan kegiatan panen ikan diangkat dari kolam seharga Rp.500.000 per empang atau kolam dan untuk biaya angkut dari jaring sampai kendaraan sebesar Rp.500/kg. biasanya untuk panen sampai 
dengan siap di bawa untuk transportasi membutuhkan kurang lebih 5 orang, jumlah tenaga bantu untuk panen tergantung jumlah hasil panen, bobot ikan dan lokasi panen. Pengisian oksigen menggunakann tabung oksigen ukuran $6 \mathrm{~m}^{2}$, biaya pengisian oksigen sebesar Rp.75.000 untuk satu tabung. Satu tabung oksigen cukup untuk mengisi oksigen ikan dalam plastik sebanyak kurang lebih $1000 \mathrm{~kg}$.

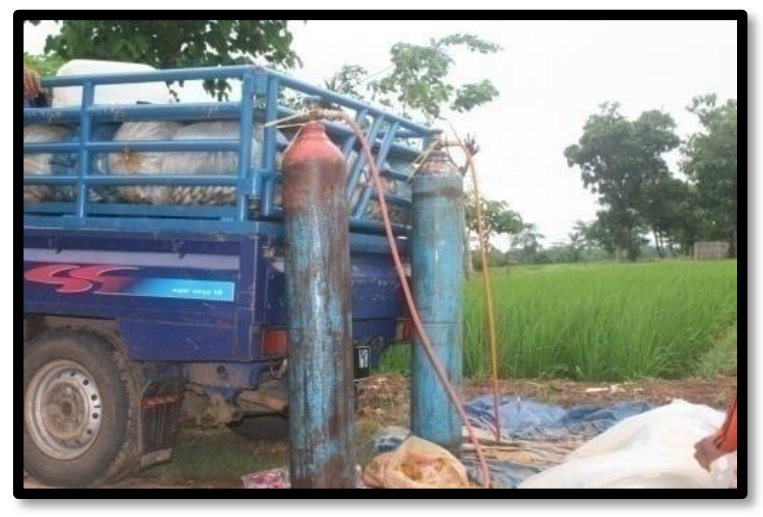

Gambar 16. Jenis tabung yang digunakan

Kegiatan transportasi ikan di petani pembesar Kabupaten Bogor biasanya menggunakan kendaraan berupa truk, mobil bak terbuka, dan motor karena para petani ikan di sana menerima penjualan secara partai kecil hingga partai besar. Permasalahan yang terjadi di sana ialah banyak petani mengalami kesulitan untuk menjual ikan mereka terutama di daerah dengan kondisi wilayah yang sulit dijangkau seperti di kecamatan Pamijahan yang terletak di kaki gunung, namun terdapat beberapa petani yang sudah memiliki pembeli tetap yang bisa disebut juga tengkulak yang sudah siap menampung ikan hasil panen petani tersebut.

\section{E. Harga Ikan}

Harga ikan Mas yang dijual bervariasi tergantung ukuran dan musim yang sedang terjadi di wilayah tersebut. Semakin kecil ukuran ikan yang dijual semakin tinggi pula harga jual ikan tersebut, ini berlaku untuk ikan yang masuk dalam kategori benih. Salah satu contoh bisa dilihat harga ikan ukuran 100 ekor/kg dijual dengan harga Rp.28.000 - Rp.32.000 sedangkan ukuran ikan 100 ekor/Liter dijual dengan harga Rp.40.000 - Rp.50.000 dan ukuran 5000 ekor/Liter dijual dengan harga Rp.100.000 - Rp.120.000 dan itu harga dari petani ikan, tentu saja harga berubah setelah sampai di Bandar. Margin atau selisih harga yang terjadi dari petani hingga Bandar adalah sekitar Rp.10.000 - Rp.20.000 karena Bandar menghitung juga dengan biaya transportasi. Harga ikan Mas yang dijual dimulai dari petani pembenih di Kabupaten Subang dapat dilihat di Tabel 9 berikut.

Tabel 9. Harga Ikan Mas Ukuran Benih di Kabupaten Subang

\begin{tabular}{|l|l|l|ll|}
\hline No & \multicolumn{1}{|c|}{ Ukuran } & \multicolumn{1}{|c|}{ Petani pembenih } & \multicolumn{1}{|c|}{ Tengkulak } \\
\hline 1 & Kebul $(1-3 \mathrm{~cm})$ & Rp.2,00,-/ekor & Rp.2,50,-/ekor \\
\hline 2 & $\begin{array}{l}\text { Burayak 1000 - 5000 } \\
\text { ekor/Liter }\end{array}$ & $\begin{array}{l}\text { Rp.100.000,- }- \\
\text { Rp.150.000,-/Liter }\end{array}$ & $\begin{array}{l}\text { Rp.110.000,- } \\
\text { Rp.170.000,-/Liter }\end{array}$ \\
\hline 3 & Benih 100 ekor/kg & $\begin{array}{l}\text { Rp.30.000,- }- \\
\text { Rp.32.000,-/kg }\end{array}$ & $\begin{array}{l}\text { Rp.32.000,- } \\
\text { Rp.35.000,-/kg }\end{array}$ \\
\hline
\end{tabular}

Untuk harga ikan di Kabupaten Bogor dijual dimulai dari ukuran konsumsi (300 - 700 g/ekor) sampai ukuran untuk pemancingan (1,5 - $5 \mathrm{Kg}$ /ekor) dapat dilihat di Tabel 10 berikut: Tabel 10. Harga Ikan Ukuran Konsumsi di Kecamatan Pamijahan 


\begin{tabular}{|c|l|c|}
\hline No & \multicolumn{1}{|c|}{ Ukuran } & Petani Pembesar \\
\hline 1 & $300-700$ g/ekor & Rp. $21.500-\mathrm{Rp} .22 .500 / \mathrm{kg}$ \\
\hline 2 & $700-1000$ g/ekor & $\mathrm{Rp} .23 .000-\mathrm{Rp} .24 .000 / \mathrm{kg}$ \\
\hline 3 & $1,5 \mathrm{~kg}$ & $\mathrm{Rp} .25 .000-\mathrm{Rp} .27 .000 / \mathrm{kg}$ \\
\hline 4 & $2 \mathrm{~kg}$ & $\mathrm{Rp} .28 .000-\mathrm{Rp} .30 .000 / \mathrm{kg}$ \\
\hline 5 & $3 \mathrm{~kg}$ & $\mathrm{Rp} .35 .000-\mathrm{Rp} .38 .000 / \mathrm{kg}$ \\
\hline 6 & $4 \mathrm{~kg}$ & $\mathrm{Rp} .40 .000-\mathrm{Rp} .42 .000 / \mathrm{kg}$ \\
\hline 7 & $5 \mathrm{~kg}$ & $\mathrm{Rp} .50 .000-\mathrm{Rp} .52 .000 / \mathrm{kg}$ \\
\hline
\end{tabular}

Tabel di atas menunjukkan ada ciri khas tertentu dalam penjualan ikan baik pada ikan ukuran konsumsi dimana ikan semakin besar maka semakin mahal pula harga yang harus dibayarkan. Harga yang ditampilkan di atas merupakan harga dari petani kepada Bandar atau tengkulak sebelum proses transportasi. Biaya transportasi dibebankan tergantung kepada kesepakatan pihak penjual dengan pihak pembeli, biasanya pembeli datang langsung atau menelpon penjual (dalam hal ini tengkulak) dan membeli ikan dengan harga tidak termasuk biaya transportasi.

Harga jual berbeda setelah dibeli tengkulak, pedagang pengecer, dan pedagang perantara. Selisih harga (marjin pemasaran) yang terjadi dari harga jual di petani ikan hingga di pedagang perantara sekitar Rp.5.500. Dalam Tabel 11 dan 12 berikut dijelaskan harga ikan di tingkat tengkulak sampai konsumen.

Tabel 11. Harga di Tingkat Tengkulak Sampai Pedagang Pengecer

\begin{tabular}{|l|l|l|l|l|}
\hline \multirow{2}{*}{ No } & \multicolumn{2}{|c|}{ Tengkulak } & \multicolumn{2}{c|}{ Pedagang Pengecer } \\
\cline { 2 - 5 } & $300-700$ g/ekor & $700-1000$ g/ekor & $300-700$ g/ekor & $700-1000$ g/ekor \\
\hline 1 & Rp.24.000 & - & Rp.27.000 & - \\
\hline 2 & Rp.23.000 & - & Rp.26.000 & - \\
\hline 3 & Rp.24.000 & - & Rp.27.000 & - \\
\hline
\end{tabular}

Dalam Tabel 12 di bawah ini dijelaskan harga ikan Mas di tingkat pengecer dan perantara, dimana selisih harga yang terjadi antara pedagang pengecer dan pedagang perantara atau biasa orang setempat menyebutnya 'calo'sebesar Rp.500,-. Tabel 12.

Harga di Tingkat Pedagang Pengecer sampai Pedagang Perantara

\begin{tabular}{|l|l|l|l|l|}
\hline \multirow{2}{*}{ No } & \multicolumn{2}{|c|}{ Pedagang Pengecer } & \multicolumn{2}{c|}{ Pedagang Perantara } \\
\cline { 2 - 5 } & $300-700$ g/ekor & $700-1000$ g/ekor & $300-700$ g/ekor & $700-1000$ g/ekor \\
\hline 1 & Rp.27.000 & - & Rp.27.500 & - \\
\hline 2 & Rp.26.000 & - & Rp.26.500 & - \\
\hline 3 & Rp.27.000 & - & Rp.27.500 & - \\
\hline
\end{tabular}

Marjin pemasaran adalah perbedaan harga yang dibayarkan kepada produsen dan harga yang dibayar oleh konsumen. marjin pemasaran yang terjadi di Kecamatan Pamijahan dapat dilihat di Tabel 13 dan 14.

Tabel 13. Marjin Harga Ikan Mas dari pedagang pengecer di Kecamatan Pamijahan

\begin{tabular}{|c|c|c|c|}
\hline \multirow{2}{*}{ No } & \multicolumn{2}{|c|}{ Ukuran $300-700$ g/ekor } & \multirow{2}{*}{ Marjin Pemasaran } \\
\cline { 2 - 3 } & Pedagang pengecer & Petani Ikan & \\
\hline 1 & Rp.27.000 & Rp.22.000 & Rp.5.000 \\
\hline 2 & Rp.26.000 & Rp.21.000 & Rp.5.000 \\
\hline
\end{tabular}




\begin{tabular}{|l|l|l|l|}
\hline 3 & Rp.26.000 & Rp.21.000 & Rp.5.000 \\
\hline
\end{tabular}

Dari Tabel 13 di atas dapat dilihat bahwa marjin/selisih dari petani ikan sebagai produsen hingga ke pedagang pengecer adalah Rp.5.000, sedangkan pada Tabel 14 di bawah ini dijelaskan marjin/selisih harga yang terjadi dari produsen sampai ke pedagang perantara sebesar Rp.5.500.

Tabel 14. Marjin Harga Ikan Mas dari pedagang perantara di Kecamatan Pamijahan

\begin{tabular}{|c|c|c|c|}
\hline \multirow{2}{*}{ No } & \multicolumn{2}{|c|}{ Ukuran $300-700$ g/ekor } & \multirow{2}{*}{ Marjin Pemasaran } \\
\cline { 2 - 3 } & Pedagang perantara & Petani Ikan & Rp.5.500 \\
\hline 1 & Rp.27.500 & Rp.22.000 & Rp.5.500 \\
\hline 2 & Rp.26.500 & Rp.21.000 & Rp.5.500 \\
\hline 3 & Rp.26.500 & Rp.21.000 & \\
\hline
\end{tabular}

Biaya transportasi tergantung kepada jenis mobil dan jarak yang ditempuh, untuk mobil jenis carry 1.5 dengan daya tampung maksimal $500 \mathrm{Kg}$ dengan jarak tempuh $3-5$ jam perjalanan dikenakan biaya sebesar Rp.500.000 - Rp.550.000 untuk satu kali perjalanan. Berbeda dengan mobil dengan jenis L300 yang mempunyai daya tampung maksimal $650 \mathrm{Kg}$ dengan waktu yang sama dikenakan biaya Rp.700.000 - Rp.750.000.

Pada proses transportasi jumlah ikan mengalami penyusutan karena terjadinya kematian ikan saat sampai ke lokasi pengiriman. Hal itu terjadi karena jarak tempuh yang jauh dan cukup lama. Jumlah ikan yang mati biasanya berkisar $1-15 \%$ dari jumlah total ikan. Pada saat kendaraan transportasi sampai tujuan ikan kembali dihitung untuk memastikan kembali jumlah total ikan yang dibeli dan jumlah ikan yang mati saat perjalanan. Pada saat itu pembeli dan penjual menghitung kembali nilai jual beli yang telah disepakati sebelum ikan dikirim dan sampai ke tujuan.

\section{F. Rantai Pemasaran}

Hasil pemasaran ikan Mas di Kabupaten Bogor tidak memiliki rantai pemasaran yang panjang. Petani menjual langsung ke tengkulak atau ke konsumen akhir, sehingga menyebabkan pihak terkait kesulitan dalam mendata jenis ikan dan berapa jumlah ikan yang dijual, maka data yang di dapat kurang lengkap. Pemasaran di Kabupaten Bogor tidak tertata dengan baik karena pada daerah tertentu ada yang bisa menjual ikan mereka dengan mudah karena berdekatan dengan pasar dan aksesnya pun mudah seperti di daerah Ciseeng yang biasa menjual ikan mereka di pasar Parung tetapi ada juga yang kesulitan menjual seperti di daerah Pamijahan karena akses yang cukup sulit berada di kaki gunung dan jauh dari pasar. Alur pemasaran yang terjadi di Kabupaten Bogor dapat dilihat

di Gambar 17 berikut.

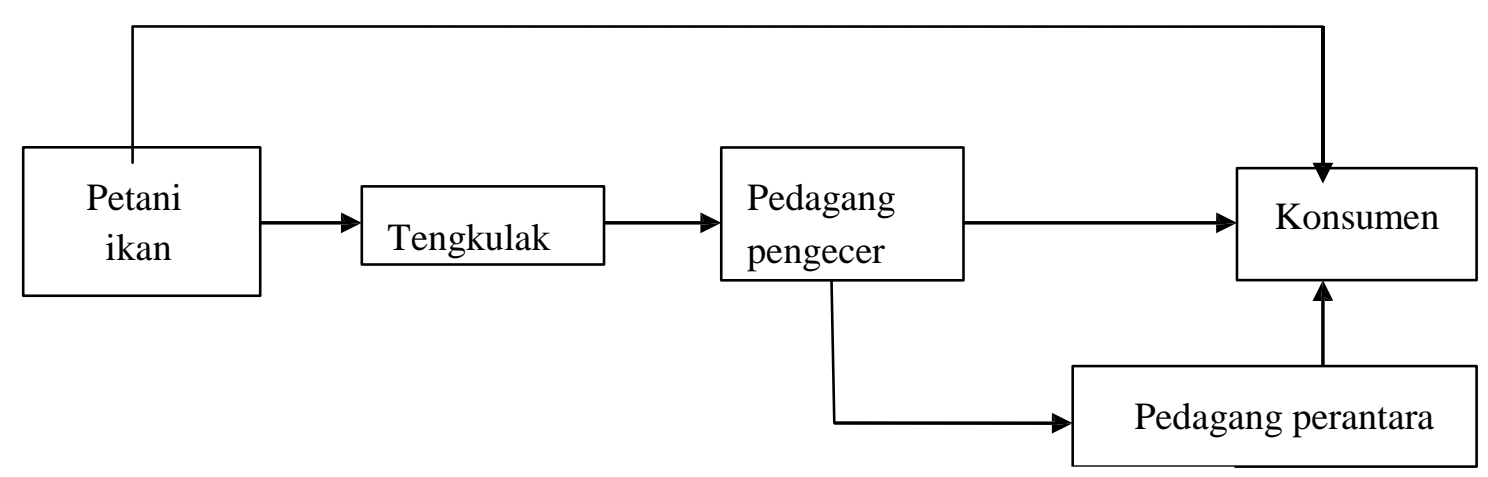

Gambar 17. Alur Pemasaran di Kabupaten Bogor 
Pada gambar di atas dapat dijelaskan bahwa pada alur pemasaran pertama petani ikan menjual langsung ke konsumen akhir, ini banyak terjadi pada ikan ukuran pemancingan atau bobot $>1$ $\mathrm{kg}$ /ekor. pada alur pemasaran kedua petani ikan menjual ikan mereka ke tengkulak dan tengkulak menjual ikan mereka ke pedagang pengecer dan menjual kembali ke konsumen akhir. Pada alur ketiga petani ikan menjual ikan mereka ke tengkulak lalu menjual kembali ke pedagang pengecer dan pedagang pengecer menyewa jasa calo untuk membantu menjual ikan mereka ke konsumen.

\section{A. Kesimpulan}

\section{KESIMPULAN DAN SARAN}

Rantai pemasaran di Kabupaten Bogor terdiri dari tiga alur pemasaran dimulai dari petani ikan sebagai produsen sampai ke konsumen. Pola pertama ialah produsen menjual langsung ikan mereka ke konsumen akhir. Ini terjadi pada ikan untuk jenis pemancingan atau ikan dengan bobot $>1$ $\mathrm{kg}$ /ekor, pola kedua ialah petani ikan menjual ikan mereka ke pedagang perantara lalu pedagang perantara menjual kembali ikan tersebut ke konsumen akhir, dan pola ketiga ialah petani ikan menjual ke pedagang perantara lalu menjual ke konsumen akhir melalui jasa pedagang perantara. Petani ikan mengalami kesulitan dalam menjual ikan mereka sehingga mereka membentuk kelompok tani dengan tujuan mempermudah pemasaran ikan Mas mereka dan menambah jumlah konsumen mereka yang datang membeli. Harga jual ikan Mas ukuran konsumsi dengan ukuran 300 - 1000 g/ekor dijual dengan harga rata - rata Rp.22.000/kg, sedangkan ukuran pemancingan dengan ukuran terbesar yaitu $5 \mathrm{~kg}$ dijual dengan harga rata - rata Rp.50.000/kg dari petani. Harga ikan ukuran konsumsi sampai pada konsumen akhir melalui pedagang perantara berkisar di Rp.27.000,-.

\section{B. Saran}

Adanya bantuan dari pemerintah setempat atau lembaga keuangan berupa modal, sehingga petani ikan di Kecamatan Pamijahan tidak mengalami kesulitan dalam peminjaman modal. Adanya kerja sama dari pemerintah dengan petani ikan untuk meningkatkan nilai jual dan pemasaran ikan Mas di Kecamatan Pamijahan Kabupaten Bogor.

\section{DAFTAR PUSTAKA}

Anggaini, S., 2008. Analisis Kelayakan Finansial Usaha Ikan Mas (Cyprinus carpio) Dengan Cara Pemberokan (Kasus: Desa Selajambe, Kecamatan Cisaat, Kabupaten Sukabumi, Propinsi Jawa Barat). Skripsi. Institut Pertanian Bogor. Bogor

Hanafiah, A.M. dan Saefuddin, A.M., 2006. Tata Niaga Hasil Perikanan. Penerbit Universitas Indonesia.

Noviana .C .D., 2003 Analisis Ikan Laut Segar di Kabupaten Cilacap. Fakultas Ekonomi Universitas Sebelas Maret. Surakarta.

Sudiyono, A., 2004. Pemasaran Pertanian. Universitas Muhamadiyah Malang. Malang. 